\title{
RESPON PERTUMBUHAN DAN HASIL GARUT (MARANTA ARUNDINACEA) TERHADAP PEMBUMBUNAN DAN PEMUPUKAN KALIUM
}

\author{
Rahmawati Fitria"), Supriyono ${ }^{2)}$, Sudadi $^{2)}$ \\ 1) Mahasiswa S1 Program Studi Agroteknologi, Fakultas Pertanian, Universitas Sebelas Maret \\ 2) Staf Dosen Program Studi Agroteknologi, Fakultas Pertanian, Universitas Sebelas Maret
}

Author Contact: rahmawati.fitria98@gmail.com

\begin{abstract}
This research aims to determine the arrowroot responses on piling and potassium fertilizer application on its growth and yield. This research was conducted in Experiment Field of Agriculture Faculty SebelasMaret University at Sukosari, Jumantono, Karanganyar using Randomized Completed Block Design (RCBD) factorial with two factors of piling and potassium fertilization. There are 2 levels of piling, consists of without piling treatment (P0) and with in piling (P1). There are 3 levels of potassium fertilization consist of $250 \mathrm{~kg} \mathrm{ha}^{-1} \mathrm{KCl}, 300 \mathrm{~kg} \mathrm{ha}^{-1} \mathrm{KCl}$, and $350 \mathrm{~kg} \mathrm{ha}^{-1}$ $\mathrm{KCl}$. Observation variable consist of plant height, leaf number, tiller number, biomass fresh weight per plant, biomass dry weight per plant, tuber numbers per plant, tuber weights per plant, tuber weights per plot, tuber diameter, and tuber length. Data were analyzed using analysis of variance and if there is significant difference, continue with DMRT (Duncan's Multiple Range Test) of $5 \%$ level. The result showed that treatment with in piling (P1) can tends to increase yield of arrowroot plant on tuber numbers per plant, tuber weights per plant, and tuber weights per plot. Potassium fertilizer treatment with $350 \mathrm{~kg} \mathrm{ha}^{-1}$ dose $\mathrm{KCl}$ tends to increase at growth and yield in all variables except the tiller numbers.
\end{abstract}

Keywords: tuber yield, dosage, starch

AGROTECHNOLOGY RESEARCH JOURNAL

Fitria R, Supriyono, Sudadi. 2017. Growth responses and yield of arrowroot (Maranta arundinacea) on piling and potassium fertilization. Agrotech Res J 1(1): 46-50.

Fitria R, Supriyono, Sudadi. 2017. Respon pertumbuhan dan hasil garut (Maranta arundinacea) terhadap pembumbunan dan pemupukan kalium. Agrotech Res J 1(1): 46-50.

\section{PENDAHULUAN}

Indonesia merupakan salah satu negara dengan konsumsi beras yang tinggi dari data tahun 2012 melakukan impor beras sebanyak 1.810.372 ton (Sari 2014). Bahan pangan alternatif diperlukan untuk mengatasi kebutuhan pangan yang semakin meningkat salah satunya dari tanaman umbi-umbian karena mengadung karbohidrat (Djaafar et al 2010). Tanaman yang mengandung karbohidrat dan dapat digunakan seperti singkong, ubi, dan garut. Garut memiliki umbi yang tumbuh meluas (Yenrina et al 2016) dan merupakan salah satu bahan pangan alternatif yang dapat digunakan karena mengandung pati, dimana kandungan pati garut ini dapat digunakan untuk pengganti tepung terigu. Umbi garut yang mampu dihasilkan oleh tanaman sebanyak 9-12 ton ha-1 memiliki kandungan pati sebanyak 1,92-2,56 ton ha ${ }^{-1}$ (Djaafar et al 2010). Garut merupakan tanaman tropis (Tan dan Zaharah 2015) dengan umbi yang berwarna putih, berbentuk silinder memanjang, dan beruas (Malinis dan Pacardo 2012). Garut mengadung indeks glikemik yang rendah tetapi kandungan karbohidratnya tinggi sehingga dapat digunakan sebagai bahan pangan alternatif (Hadiatmi dan Suhartini 2011). Garut mengandung pati dan beberapa komponen lain seperti amilosa $25,9 \%, 0,19 \%$ protein, dan $0,84 \%$ lemak (Harmayani et al 2011). Masyarakat melakukan budidaya garut sebagai tanaman pekarangan dan tanaman sela dengan masa tanam 6-10 bulan di bawah naungan tanaman lain (Djaafar et al 2010), belum ditanam sebagai tanaman utama pada suatu lahan (Yudianto et al 2015). Umbi tanaman garut memerlukan penanganan yang cepat karena umbinya sangat mudah rusak (Igbabul et al 2012). Upaya peningkatan hasil panen garut dapat dilakukan melalui pembumbunan dan pemupukan kalium. Pembumbunan berfungsi untuk melindungi umbi dari serangan hama (Yudianto et al 2015), menghindari umbi muncul ke permukaan tanah (Hamdani 2009), dan memperbaiki sirkulasi udara di dalam tanah (Djahidun et al 2014). Pupuk kalium mengandung unsur $\mathrm{K}$ yang diperlukan tanaman dalam proses pengisian umbi. Kalium berperan dalam memperkuat batang tanaman dengan penebalan batang melalui peningkatan kadar sklerenkim (Silahooy 2008), tanaman tahan terhadap serangan penyakit, umur simpan umbi menjadi lebih panjang, kepadatan umbi tetap terjaga (Gunadi 2009), meningkatkan berat umbi, jumlah umbi, dan diameter umbi (Kalwiya et al 2015).

Unsur kalium juga berperan dalam translokasi karbohidrat (Brar dan Tiwari 2004), pengendalian osmotik, turgor sel (Taiz dan Zeger 2002), translokasi gula pembentuk pati, meningkatkan ketahanan terhadap kekeringan, dan memperluas pertumbuhan akar (Novizan 2002). Penelitian ini dilakukan untuk mengetahui pembumbunan dan dosis pupuk kalium yang tepat untuk pertumbuhan dan hasil garut. 


\section{BAHAN DAN METODE}

Penelitian ini dilaksanakan di Lahan Percobaan Fakultas Pertanian, Universitas Sebelas Maret Surakarta di Desa Sukosari, Kecamatan Jumantono, Kabupaten Karanganyar pada Maret-September 2016. Bahan yang digunakan yaitu benih vegetatif garut berumur 3 bulan dan pupuk $\mathrm{KCl}$. Penanaman garut dengan jarak tanam $30 \mathrm{~cm} \times 40 \mathrm{~cm}$, sehingga luas tiap petakan percobaan $5,76 \mathrm{~m}^{2}$. Alat yang digunakan selama penelitian terbagi menjadi dua yaitu lapang dan laboratorium. Alat yang digunakan saat lapang yaitu cangkul, cetok, meteran, gunting, selang air, tali rafia, timbangan digital, dan jangka sorong. Alat yang digunakan di laboratorium meliputi oven, timbangan analitik, $\mathrm{pH}$ meter, spektrofotometer, flamefotometer, erlenmeyer, gelas ukur, pipet, labu takar.

Percobaan ini dilaksanakan menggunakan Rancangan Acak Kelompok Lengkap (RAKL) faktorial dua faktor dan diulang sebanyak empat ulangan. Faktor pertama yaitu pembumbunan (tanpa pembumbunan dan dengan pembumbunan) dan faktor kedua yaitu pupuk kalium (KCl $250 \mathrm{~kg} \mathrm{ha}^{-1}, 300 \mathrm{~kg} \mathrm{ha}^{-1}, 350 \mathrm{~kg} \mathrm{ha}^{-}$ $\left.{ }^{1}\right)$. Data dianalisis menggunakan analisis ragam (ANOVA) kemudian apabila terdapat beda nyata dilanjutka dengan uji DMRT (Duncan's Multiple Range Test) taraf $5 \%$. Variabel pengamatannya terdiri dari analisis k-tersedia tanah (akhir), tinggi tanaman, jumlah daun, jumlah anakan, jumlah umbi per tanaman, berat umbi per tanaman, berat umbi per petak, berat segar brangkasan per tanaman, berat kering brangkasan per tanaman, diameter umbi, dan panjang umbi.

\section{HASIL DAN PEMBAHASAN}

\section{Kondisi umum lokasi penelitian}

Lokasi penelitian berada di Desa Sukosari, Kecamatan Jumantono, Kabupaten Karanganyar dengan luas lahan percobaan $147,96 \mathrm{~m}^{2}$ terletak pada $7^{\circ}$ 37' 48,3" LS dan 1105' 51,2” BT. Lahan ini terletak pada $170 \mathrm{mdpl}$ dengan jenis tanahnya Alfisol. Curah hujan pada bulan Maret-September tergolong rendahtinggi, dengan curah hujan tertinggi pada Maret yaitu $512 \mathrm{~mm} / \mathrm{bulan}$ dan curah hujan terrendah pada Agustus yaitu $35 \mathrm{~mm} /$ bulan. Suhu rata-ratanya berkisar 27,1 $28,0^{\circ} \mathrm{C}$ dan kelembaban rata-ratanya berkisar 80,0 $86,3 \%$.

\section{Hasil}

Hasil penelitian pengaruh pembumbunan dan pemupukan kalium terhadap pertumbuhan dan hasil garut tersaji pada Tabel 1 dan 2. Pembumbunan yang dilakukan tidak berpengaruh nyata pada seluruh variabel pengamatan kecuali k-tersedia tanah. Dosis pupuk kalium yang diaplikasikan tidak berpengaruh nyata pada seluruh variabel pengamatan. Kedua perlakuan tidak saling berinteraksi.
Tabel 1 Pengaruh pembumbunan dan pemupukan kalium terhadap pertumbuhan dan hasil garut (Maranta arundinacea)

\begin{tabular}{|c|c|c|c|}
\hline \multirow[b]{2}{*}{ Variabel } & \multicolumn{3}{|c|}{ Pembumbunan } \\
\hline & \multicolumn{2}{|c|}{$\begin{array}{l}\text { Tanpa } \\
\text { Pembumbu } \\
\text { nan }\end{array}$} & $\begin{array}{l}\text { Dengan } \\
\text { Pembumbu } \\
\text { nan }\end{array}$ \\
\hline $\begin{array}{l}\text { K-Tersedia tanah } \\
(\mathrm{me} / 100 \mathrm{~g})\end{array}$ & \multicolumn{2}{|c|}{$4,29^{\mathrm{a}}$} & $3,10^{b}$ \\
\hline $\begin{array}{l}\text { Tinggi tanaman } \\
\text { (cm) }\end{array}$ & \multicolumn{2}{|r|}{51,52} & 51,77 \\
\hline $\begin{array}{l}\text { Jumlah daun } \\
\text { (helai) }\end{array}$ & \multicolumn{2}{|r|}{20,39} & 20,09 \\
\hline $\begin{array}{l}\text { Jumlah anakan } \\
\text { (anakan) }\end{array}$ & \multicolumn{2}{|r|}{3,18} & 3,24 \\
\hline $\begin{array}{l}\text { Berat kering } \\
\text { brangkasan (g) }\end{array}$ & \multicolumn{2}{|r|}{34,43} & 38,30 \\
\hline $\begin{array}{l}\text { Jumlah umbi per } \\
\text { tanaman (umbi) }\end{array}$ & \multicolumn{2}{|r|}{6,06} & 6,11 \\
\hline $\begin{array}{l}\text { Berat umbi per } \\
\text { petak }(\mathrm{kg})\end{array}$ & \multicolumn{2}{|r|}{6,45} & 6,52 \\
\hline $\begin{array}{l}\text { Diameter umbi } \\
(\mathrm{cm})\end{array}$ & \multicolumn{2}{|r|}{2,57} & 2,54 \\
\hline $\begin{array}{l}\text { Panjang umbi } \\
(\mathrm{cm})\end{array}$ & \multicolumn{2}{|r|}{18,76} & 18,51 \\
\hline \multirow[b]{2}{*}{ Variabel } & \multicolumn{3}{|c|}{ Pupuk Kalium } \\
\hline & $\begin{array}{r}250 \mathrm{~kg}^{-} \\
\mathrm{KCl} \mathrm{ha}^{-1}\end{array}$ & $\begin{array}{r}300 \mathrm{~kg} \\
\mathrm{KCl} \mathrm{ha-1}\end{array}$ & $\begin{array}{r}350 \mathrm{~kg}^{-1} \\
\mathrm{KCl} \mathrm{ha}\end{array}$ \\
\hline $\begin{array}{l}\text { K-Tersedia } \\
\text { tanah (me/100 } \\
\text { g) }\end{array}$ & 3,88 & 3,51 & 3,69 \\
\hline $\begin{array}{l}\text { Tinggi tanaman } \\
\text { (cm) }\end{array}$ & 51,27 & 50,79 & 52,88 \\
\hline $\begin{array}{l}\text { Jumlah daun } \\
\text { (helai) }\end{array}$ & 19,86 & 20,34 & 20,53 \\
\hline $\begin{array}{l}\text { Jumlah anakan } \\
\text { (anakan) }\end{array}$ & 3,17 & 3,36 & 3,10 \\
\hline $\begin{array}{l}\text { Berat kering } \\
\text { brangkasan per } \\
\operatorname{tanaman}(\mathrm{g})\end{array}$ & 36,02 & 35,02 & 38,06 \\
\hline $\begin{array}{l}\text { Jumlah umbi } \\
\text { per tanaman } \\
\text { (umbi) }\end{array}$ & 5,59 & 6,13 & 6,54 \\
\hline $\begin{array}{l}\text { Berat umbi per } \\
\text { petak }(\mathrm{kg})\end{array}$ & 6,32 & 6,52 & 6,61 \\
\hline $\begin{array}{l}\text { Diameter umbi } \\
(\mathrm{cm})\end{array}$ & 2,56 & 2,54 & 2,57 \\
\hline $\begin{array}{l}\text { Panjang umbi } \\
\text { (cm) }\end{array}$ & 18,35 & 18,69 & 18,85 \\
\hline
\end{tabular}

Catatan: Angka tanpa diikuti huruf menunjukkan tidak berbeda nyata pada uji Duncan (DMRT) 0,05

\section{K-tersedia tanah}

Hasil analisis ragam pada k-tersedia tanah menunjukkan pembumbunan berpengaruh nyata pada k-tersedia. Hasil k-tersedia pada PO (tanpa pembumbunan) lebih tinggi yaitu 4,29 me/100 gr dibandingkan dengan $\mathrm{P} 1$ (dengan pembumbunan) yaitu 3,10 me/100 gr. Hal ini dimungkinkan pada P1 (dengan pembumbunan) tanaman mudah untuk membentuk umbi sehingga umbi yang dihasilkan banyak. Hasil umbi garut yang banyak memerlukan 
unsur hara yang banyak pula sehingga akar tanaman menyerap unsur hara yang ada di tanah untuk memenuhi kebutuhan tanaman dalam pembentukan umbi tanaman. Penurunan kesuburan pada lahan dapat terjadi karena eksploitasi unsur hara oleh tanaman penghasil karbohidrat seperti umbi-umbian (Djaafar et al 2010). Syakir dan Gusmaini (2012), menyatakan bahwa kebutuhan $\mathrm{K}$ oleh tanaman cukup tinggi sehingga apabila tidak terpenuhi maka proses metabolismenya terganggu. Yusron et al (2003), mengemukakan bahwa hasil panen 1 ton umbi mengadung $36 \mathrm{~kg} \mathrm{~K}, 5 \mathrm{~kg} \mathrm{P}$, dan $16 \mathrm{~kg} \mathrm{~N}$ yang setara dengan KCl 144,60 kg, SP-36 63,61 kg, dan 35,56 kg urea. Kesuburan tanah agar tetap seimbang, maka dilakukan pengembalian unsur hara yang hilang. Faktor lain yang diduga berpengaruh terhadap k-tersedia tanah yaitu akibat terjadinya erosi kecil pada P1 dan terlindi saat hujan atau hilang saat penyiraman. Tanah pada perlakuan dengan pembumbunan (P1) lebih gembur dan remah sehingga air mudah masuk ke dalam tanah dan melindi unsur hara pada tanah sesuai dengan pernyataan Novizan (2002), bahwa kalium dalam tanah dapat hilang akibat erosi tanah, pencucian oleh air atau akibat diserap oleh tanaman. Rosalyne (2010) menyatakan, pengolahan tanah meningkatkan kehilangan kadar bahan organik akibat tanah yang mudah tererosi.

\section{Tinggi tanaman}

Hasil analisis ragam tinggi tanaman menunjukkan perlakuan yang diberikan yaitu pembumbunan dan pupuk kalium tidak berpengaruh nyata terhadap variabel tinggi tanaman. Berdasarkan Tabel 1 terlihat bahwa tinggi tanaman tertinggi terdapat pada $\mathrm{P} 1$ (dengan pembumbunan) yaitu $51,77 \mathrm{~cm}$. Tanaman dengan pembumbunan (P1) lebih mudah dalam mencari unsur hara karena tanahnya yang gembur sehingga memudahkan akar tanaman dalam mencari dan menyerap unsur hara dari dalam tanah. Penyerapan nutrisi yang cukup cenderung mampu meningkatkan tinggi tanaman garut sesuai dengan penyataan Yudianto et al (2015), dengan semakin banyak frekuensi pembumbunan yang dilakukan maka nilai rata-rata pada luas daun, jumlah daun, dan tinggi tanaman semakin meningkat.

Hasil tertinggi pada perlakukan pupuk kalium ditunjukkan pada taraf perlakuan K3 yaitu $52,88 \mathrm{~cm}$. Pemberian pupuk kalium tidak berpengaruh nyata terhadap tinggi tanaman, namun cenderung lebih tinggi hasilnya dibandingkan pemberian pupuk kalium pada dosis yang lebih rendah. Motaghi dan Tayeb (2014), menyatakan dengan aplikasi pupuk kalium cenderung untuk meningkatkan tingkat pertumbuhan tanaman. Aplikasi pupuk yang dilakukan dapat meningkatkan jumlah daun dan tinggi tanaman dengan mempengaruhi proses metabolisme dan pembentukan sel-sel tanaman. Produksi tanaman yang dapat ditingkatkan berupa jumlah umbi, berat umbi, dan diameter umbi (Kalwiya et al 2015).

\section{Jumlah daun}

Hasil pada Tabel 1 menunjukkan rerata perlakuan pembumbunan tidak berpengaruh nyata terhadap jumlah daun. Perlakuan dengan pembumbunan (P1) cenderung lebih rendah hasilnya dibandingkan tanpa pembumbunan (P0) yaitu 20,09 helai. Faktor yang mempengaruhi jumlah daun yaitu adanya daun tua yang gugur dan anakan yang muncul mati, sehingga jumlah daun keseluruhan berkurang sesuai dengan Lestari et al (2008), menyatakan perbedaan jumlah daun keseluruhan dipengaruhi oleh jumlah daun anakan yang muncul serta adanya pengguguran daun tua.

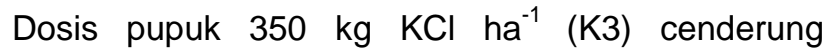
meningkatkan jumlah daun tanaman yaitu 20,53 helai. Unsur hara $\mathrm{K}$ pada dosis $350 \mathrm{~kg} \mathrm{KCl} \mathrm{ha}{ }^{-1}$ masih kurang efektif untuk memenuhi kebutuhan tanaman dalam pertumbuhan, sedangkan unsur hara yang mampu mendukung pemunculan daun yaitu unsur $\mathrm{N}$ dan $\mathrm{P}$ sejalan dengan Sudradjat et al (2014), pemberian pupuk $\mathrm{N}$ mampu meningkatkan jumlah daun secara linier maupun kuadratik. Pupuk $P$ berpengaruh terhadap jumlah daun tanaman secara linier. Safuan dan Andi (2012), menyatakan jumlah dan ukuran daun dipengaruhi oleh lingkungan tumbuh dan ketersediaan unsur hara.

\section{Jumlah anakan}

Hasil rerata pembumbunan $(\mathrm{P} 1)$ tidak berbeda nyata dengan tanpa pembumbunan (P0), namun cenderung mampu meningkatkan jumlah anakan pada tanaman sebanyak 3,24 anakan, walaupun secara statistik tidak berpengaruh nyata. Hal ini menunjukkan bahwa dengan pembumbunan memudahkan anakan untuk tumbuh dan menembus ke permukaan tanah sehingga pembumbunan mampu memberikan rata-rata jumlah anakan yang lebih tinggi dibandingkan tanpa pembumbunan (Yudianto et al 2015).

Rerata pada dosis pupuk kalium $300 \mathrm{~kg} \mathrm{KCl} \mathrm{ha}^{-1}$ (K2) cenderung meningkatkan pemunculan jumlah anakan sebanyak 3,36 anakan. Anakan yang muncul lebih tinggi dari pada dosis yang lainnya diduga karena kemampuan tanaman dalam memacu pemunculan anakan berbeda-beda. Selain itu, pada dosis $300 \mathrm{~kg}$ $\mathrm{KCl} \mathrm{ha}{ }^{-1}$ (K2) pemupukan yang dilakukan sudah mencukupi tanaman dalam pemunculan anakan. Pemunculan anakan berkaitan dengan pertumbuhan vegetatif sesuai dengan Lestari et al (2008), bahwa jumlah anakan yang meningkat menunjukkan tanaman aktif dalam pertumbuhan.

\section{Berat kering brangkasan per tanaman}

Hasil tertinggi pada pembumbunan P1 yaitu 38,30 gr. Hasil pada pupuk kalium yang tertinggi terdapat pada K3 yaitu 38,06 gr. Hasil berat kering brangkasan berhubungan dengan berat segar brangkasan. Hasil berat segar yang tinggi maka hasil fotosintesis yang diperoleh juga tinggi, sehingga berat kering brangkasannya juga menjadi tinggi. Arifin et al (2014) menyatakan, laju fotosintesis suatu tanaman apabila berlangsung bagus dapat ditandai dengan pertumbuhan dan perkembangan tanaman yang cepat sehingga hasil fotosintat yang diperoleh semakin besar dari biomassa akar, batang dan daun.

\section{Jumlah umbi per tanaman}

Hasil sidik ragam jumlah umbi per tanaman yang dilakukan bahwa perlakuan yang diterapkan tidak 
berpengaruh nyata. Hasil jumlah umbi per tanaman yang diperoleh pada perlakuan pembumbunan (P1) yang tinggi, karena tanaman menjadi lebih mudah dalam membentuk umbi pada tanah yang gembur. Menurut Tumewu et al (2015), tanah yang baik untuk budidaya ubi kayu memiliki struktur tanah yang gembur dan remah yang dapat dipertahankan dari fase awal pertumbuhan sampai panen. Kondisi tersebut memberikan sirkulasi oksigen dan karbondioksida dalam tanah sehingga jasad renik dan fungsi akar menjadi optimal dalam penyerapan hara pupuk. Hasil tertinggi dari perlakuan pupuk kalium yaitu 6,54 umbi pada K3. Unsur kalium seharusnya mampu mendukung terbentuknya umbi, dimana kalium berperan pada translokasi karbohidrat (Brar dan Tiwari 2004). Faktor yang menjadi penyebabnya karena tanaman yang menghasilkan jumlah daun lebih banyak mampu menghasilkan asimilat lebih besar lewat fotosintesis yang lebih besar, kemudian disimpan sebagai cadangan makanan yang menentukan jumlah umbi per tanaman (Arifin et al 2014).

\section{Berat umbi per petak}

Hasil rerata tertinggi pada perlakuan pembumbunan terdapat pada $\mathrm{P} 1$ yaitu $6,52 \mathrm{~kg}$. Pembumbunan yang dilakukan dimungkinkan sudah mampu meningkatkan berat umbi per petak, walaupun tidak secara nyata. Hal ini dimungkinkan karena kemampuan tanaman dalam membentuk umbi berbeda-beda jumlahnya, sehingga apabila dihitung rerata dari keseluruhan hasilnya tinggi. Sasvita et al (2013) mengatakan, bobot umbi per petak selain dipengaruhi oleh populasi juga dipengaruhi oleh bobot umbi per tanaman.

Perlakuan pupuk kalium K3 memiliki hasil berat umbi per petak cenderung lebih tinggi dibanding dosis lainnya yaitu $6,61 \mathrm{~kg}$. Hasil berat umbi yang diperoleh dimungkinkan pada dosis pupuk K3 kebutuhan tanaman dalam membentuk umbi sudah tercukupi dengan fungsi unsur $\mathrm{K}$ dalam pengaktifan enzim sintesis pati (Patil 2011), pengendalian osmotik, turgor sel, aktivitas enzim, dan translokasi fotosintat (Taiz dan Zeger 2002). Tanaman yang mampu menghasilkan fotosintat tinggi maka hasil pada umbi juga tinggi. Peran $\mathrm{K}$ dalam fisiologis tanaman yaitu pada peningkatan dan pengembangan jaringan tanaman melalui sintesa gula sederhana, pati, dan translokasi karbohidrat (Yaseen et al 2010). Hasil berat umbi per petak pada K3 cenderung memiliki hasil yang lebih tinggi dibandingkan dengan aplikasi pupuk pada dosis yang lebih rendah, dengan fungsi unsur $\mathrm{K}$ yang mengacu pada hasil panen berupa umbi dengan kalium yang berperan penting dalam memperbaiki hasil panen (Xiumei dan Yaping 2003).

\section{Diameter umbi}

Perlakuan pembumbunan hasil diameter umbi tertinggi terdapat pada P0 yaitu 2,57 cm. Diameter umbi yang terbentuk berukuran kecil diduga dipengaruhi oleh kemampuan tanaman dalam membentuk umbi. Menurut Maulani et al (2012), berpendapat bahwa diameter umbi yang tidak bertambah besar disebabkan fungsi umbi garut disini sebagai rimpang, sehingga apabila tumbuh tunas baru maka tunas baru tersebut menggunakan cadangan makanan yang ada. hasilnya 6,11 umbi. Pembumbunan yang dilakukan seharusnya mampu mendukung terbentuknya umbi

Hasil pada perlakukan pupuk kalium tertinggi pada K3 yaitu 2,57 cm. Umbi yang terbentuk memiliki diamater yang semakin besar apabila hasil fotosintesis yang mampu disimpan semakin besar. Hasil diameter yang kurang maksimal juga dipengaruhi oleh kurang tercukupinya unsur hara lain selain $\mathrm{K}$ sesuai dengan Pahlevi et al (2016), bahwa diameter umbi yang rendah akibat hasil asimilat yang ditranslokasikan juga rendah. Hasil asimilat selain untuk fotosintesis juga untuk perkembangan umbi. Penambahan pupuk $\mathrm{K}$ yang tinggi maka hasil panennya juga tinggi namun apabila tanaman kurang unsur $\mathrm{N}$ maka asimilat yang dihasilkan rendah walaupun dengan pupuk $\mathrm{K}$ yang tinggi.

\section{Panjang umbi}

Hasil panjang umbi yang diperoleh pada tanpa pembumbunan (P0) lebih tinggi dibandingkan P1 yaitu $18,76 \mathrm{~cm}$. Lestari et al (2015), menyatakan pembentukan umbi terjadi dengan bagian ujung umbi muda yang menembus tanah untuk mencari lokasi pembesaran. Umbi memiliki bentuk lebih bulat pada tanah yang berpori lebih besar sehingga umbi berkembang optimal tetapi dengan usaha minimal.

Hasil tertinggi pada perlakuan pupuk kalium terdapat pada K3 yaitu $18,85 \mathrm{~cm}$. Umbi yang terbentuk memiliki panjang umbi yang hampir sama pada perlakuan yang berbeda, diduga panjang umbi yang terbentuk sudah optimal dan pemanjangan umbi berhenti, sesuai dengan pernyataan Sherly et al (2013) bahwa penghambatan pembentukan giberalin untuk pemanjangan sel tanaman terjadi pengalihan penggunaan karbohidrat. Karbohidrat yang terbentuk mengalami pengalihan yang semula untuk pertumbuhan vegetatif menjadi untuk pembentukan umbi.

\section{KESIMPULAN DAN SARAN}

\section{Kesimpulan}

Kesimpulan dari hasil penelitian Respon Pertumbuhan dan Hasil Garut (Maranta arundinacea L.) terhadap Pembumbunan dan Pemupukan Kalium adalah :

1. Pembumbunan, dosis pupuk kalium, dan interaksi keduanya tidak berpengaruh nyata pada seluruh variabel.

2. Perlakuan dengan pembumbunan (P1) cenderung meningkatkan hasil pada jumlah umbi per tanaman, berat umbi per tanaman, berat umbi per petak.

3. Perlakuan pupuk kalium $350 \mathrm{~kg} \mathrm{KCl} \mathrm{ha}{ }^{-1}$ (K3) cenderung meningkatkan hasil pada seluruh variabel pertumbuhan dan hasil kecuali jumlah anakan.

\section{Saran}

Penggunaan dosis pupuk yang dapat direkomendasikan untuk petani berdasarkan hasil penelitian yang diperoleh yaitu $250 \mathrm{~kg} \mathrm{KCl} \mathrm{ha}^{-1}$.

\section{DAFTAR PUSTAKA}

Arifin MS, Agung N, Agus S. 2014. Kajian panjang tunas dan bobot umbi bibit terhadap produksi 
tanaman kentang (Solanum tuberosum I.) varietas granola. J Produksi Tanaman. 2(3): 221-229.

Brar MS, Tiwari KN. 2004. Boosting seed cotton yields in Punjab eith potassium: a review. Better Crop. 88 (3): 28-31.

Djaafar TF, Sarjiman, Arlyna BP 2010. Pengembangan budidaya tanaman garut dan teknologi pengolahannya untuk mendukung ketahanan pangan. J Litbang Pertanian. 29(1): 25-33.

Djahidun N, Nikmah M, Muhamad IB. 2014. Kajian sistem olah tanah dan waktu penyiangan terhadap pertumbuhan serta hasil kacang tanah (Arachis hypogaea L.). [Artikel] Universitas Negeri Gorontalo

Gunadi N. 2009. Kalium sulfat dan kalium klorida sebagai sumber pupuk kalium pada tanaman bawang merah. J Hortikultura. 19 (2): 174-185.

Hamdani JS. 2009. Pengaruh jenis mulsa terhadap pertumbuhan dan hasil tiga kultivar kentang (Solanum tuberosum L.) yang ditanam di dataran medium. J Agron Indonesia. 37(1): 14-20.

Harmayani E, Kumalasari ID, Marsono Y. 2011. Effect of arrowroot (Maranta arundinacea L.) diet on the selected bacterial population and chemical propeties of caecal digesta of Sprague Dawley rats. Int. Res J Microbiol. 2: 278-284.

Igbabul BD, Ariahu CC, Umeh EU. 2012. Moisture desorption isotherms of African arrowroot lily (Tacca involucrata) tuber mash as influenced br blaching and natural fermentation. J Of Food Technology. 10(1):8-16.

Kalwiya HYU, Henry B, Ichwan SM. 2015. Pengaruh ukuran umbi dan dosis pupuk kalium terhadap pertumbuhan dan hasil produksi bawang merah (Allium ascalonicum L.) Varietas Lembah Palu. E-J Agrotekbis. 3 (6): 655-661.

Lestari GW, Solichatun, Sugiyarto. 2008. Pertumbuhan, Kandungan Klorofil, dan Laju Respirasi Tanaman Garut (Maranta arundinacea L.) setelah Pemberian Asam Giberelat $\left(\mathrm{GA}_{3}\right)$. Bioteknologi. 5(1):1-9.

Lestari P, Ning WU, Ninik S. 2015. Peningkatan produksi dan perbaikan ukuran umbi kentang hitam melalui teknik budidaya sebagai upaya konservasi. Bul Kebun Raya. 18 (2): 59-70.

Malinis AP, Pacardo CO. 2012. Adaptation of arrowroot (Maranta arundinacea) processing technologies in thyphoon prone marginal areas in Bicol. Int. J Sustainable Development. 4(3): 51-62

Maulani RR, Budiasih R, Nelis I. 2012. Karakterisasi fisik dan kimia rimpang dan pati garut pada berbagai umur panen. [Seminar Nasional] kedaulatan pangan dan Energi Fakultas Pertanian Trunojoyo Madura.

Motaghi S, Tayeb SN. 2014. The effect of different levels of humic acid and potassium fertilizer on physiological indices of growth. Int. J Biosciences. 5 (2): 99-105.

Novizan. 2002. Petunjuk pemupukan yang efektif. Tangerang: Agromedia Pustaka.

Pahlevi KW, Bambang G, Nur ES. 2016. Pengaruh kombinasi proporsi pemupukan nitrogen dan kalium pada pertumbuhan, hasil, dan kualitas tanaman ubi jalar (Ipomoea batatas ( L.) Lamb). Varietas cilembu pada dataran rendah. J Produksi Tanaman. 4(1):1622.
Patil RB. 2011. Role of potassium humate on growth and yield of soybean and black gram. Int J Pharma and Bio sciences. 2(1): 242-246.

Safuan LO, Andi B 2012. Pengaruh BO dan pupuk kalium terhadap pertumbuhan dan produksi tanaman melon (Cucucmis melo L.). J Agroteknos. 2(2): 69-76.

Sari RK. 2014. Analisis impor beras di Indonesia. Economics Development Analysis Journ. 3(2): 320326.

Sasvita W, Chairani H, Edison P. 2013. Pertumbuhan dan hasil tiga klon ubi jalar pada jarak tanam yang berbeda. J Online Agroekoteknologi. 2(1): 462-473.

Silahooy Ch. 2008. Efek pupuk KCl dan SP-36 terhadap kalium tersedia, serapan kalium dan hasil kacang tanah (Arachis hypogaea L.) pada tanah brunizem. Bul Agronomi. 36(2): 126-132.

Sudradjat, Anita D, Ade W. 2014. Optimasi Dosis Pupuk Nitrogen dan Fosfor pada Bibit Kelapa Sawit (Elaeis guineensis Jacq.) di Pembibitan Utama. J Agronomi Indonesia. 42(3): 222-227.

Susanto E, Ninuk H, Nue ES. 2014. Respon Pertumbuhan dan Hasil Tanaman Ubi Jalar (Ipomoea batatas L.) pada Beberapa Macam dan Waktu Aplikasi Bahan Organik. J Produksi Tanaman. 2 (5): 412-418.

Syakir M, Gusmaini. 2012. Pengaruh penggunaan sumber pupuk kalium terhadap produksi dan mutu minyak tanaman nilam. J Littri. 18(2):60-65.

Taiz L, Zeger E. 2002. Plant physiology.Massachusetts: Sinauer Associates, Inc Publisher.

Tan SL, Zaharah A. 2015. Tuber crop are under ground crops: the most important ones in Malaysia are the white potato, the sweerpotato, cassava, and cocoyam. Utar Agriculture Science J. 1(1): 41-48.

Tumewu P, Carolus PP, Tommy DS. 2015. Hasil ubi kayu terhadap perbedaan jenis pupuk. J LPPM bidang Sains dan Teknologi. 2(2): 16-27.

Xiumei L, Yaping I. 2003. An experiment on the best application amount of $\mathrm{K}_{2} \mathrm{SO}_{4}$ for potato (Solanum tuberosum) grown in chernozem soil. Chinese Potato Journ. 17: 23-24.

Yaseen AA, Habib AM, Sahar M et al. 2010. Effect of different sources of potassium fertilizer on growth, yield, and chemical composition of Caledula officinalis. J American Science. 6(12): 1044-1048.

Yenrina R, Fauzan A, Aan S. 2016. WHC and OHC of MOGAF (modify garut fluor) from arrowroot tuber (Maranta arundinacea L.) fermented spontaneously with different time. Int. $J$ of Applied Science and Technology. 6(1): 67-71.

Yudianto AA, Sisca F, Nurul A. 2015. Pengaruh jarak tanam dan frekuensi pembumbunan terhadap pertumbuhan dan hasil tanaman garut (Marantha arundinaceae L.). J Produksi Tanaman. 3 (3): 172181.

Yusron M, Gusmaini, Nurhayati H. 2003. Pemupukan N dan $\mathrm{K}$ pada garut (Marantha arundinacea) dibawah tegakan tanaman perkebunan. J Ilmiah Pertanian. $9(2): 17-24$. 